Article

\title{
A Multi-Index Analysis Approach to Heavy Metal Pollution Assessment in River Sediments in the Ponce Enríquez Area, Ecuador
}

\author{
Alby Aguilar Pesantes ${ }^{1}$, Elizabeth Peña Carpio ${ }^{1}$, Tomas Vitvar ${ }^{1} \mathbb{D}$, \\ Manuel María Mahamud López ${ }^{2}$ and Juan M. Menéndez-Aguado ${ }^{2, *} \mathbb{C}$ \\ 1 Escuela Superior Politécnica del Litoral (ESPOL), Facultad de Ingeniería en Ciencias de la Tierra, \\ Guayaquil E C090112, Ecuador; albdagui@espol.edu.ec (A.A.P.); gepena@espol.edu.ec (E.P.C.); \\ tvitvar@espol.edu.ec (T.V.) \\ 2 Escuela Politécnica de Mieres, Universidad de Oviedo, 33600 Mieres, Spain; mahamud@uniovi.es \\ * Correspondence: maguado@uniovi.es
}

Received: 25 February 2019; Accepted: 15 March 2019; Published: 21 March 2019

\begin{abstract}
The area of Ponce Enríquez, Southern Ecuador, is one of the most important artisanal and small scale gold mining (ASGM) areas in the country, where informal mining operations can be found using amalgamation technique, even though it has been prohibited since 2010. Considering the potential impact of these mining operations, the present research focused on heavy metal pollutants in subsurface sediments at 214 sampling locations from several detailed sampling campaigns in the rivers Fermín, Fermín Norte, Guanache, Villa, and Siete. Four parameters were calculated to evaluate the geochemical composition of the river sediment and heavy metal concentrations: The enrichment factor (EF), the geo-accumulation index (Igeo), the contamination factor (Cf) and the pollution load index (PLI). The analyzed elements were $\mathrm{Cu}, \mathrm{Pb}, \mathrm{Zn}, \mathrm{Ni}, \mathrm{As}, \mathrm{Cd}, \mathrm{Sb}, \mathrm{Sr}$, and $\mathrm{Hg}$. Due to the lack of standards for pollution levels in sediments in Ecuador, Canadian guidelines were used as interim sediment quality guidelines (ISQG) in this research for comparison with the obtained results in subsurface sediments. The multi-index geochemical analysis indicated elevated heavy metal concentrations in all subsurface sediments in the studied river ecosystems.
\end{abstract}

Keywords: contamination factor; environmental evaluation; enrichment factor; Igeo; pollution load index

\section{Introduction}

Precious metals, including gold, have been mined in Ecuador since the pre-Hispanic era. The traditional extraction process has caused mining pollution in various parts of the country. Appleton et al. [1] highlighted the fluvial contamination of some artisanal and small scale gold mining (ASGM) areas in Southern Ecuador. Although this study was not as exhaustive as others that can serve as a methodological reference [2], it was the first objective evidence of the existence of relevant contents of $\mathrm{As}, \mathrm{Cd}, \mathrm{Cu}$ and $\mathrm{Zn}$ in surface waters in the Ponce Enríquez, Portovelo-Zaruma, and Nambija areas. Furthermore, their results prove that those heavy metal contents exceeded the WHO Drinking Water Guideline values, the USEPA Water Quality Criteria for the Protection of Aquatic Life and the Ecuadorian standards [3].

Further research studies on sediments in the ASGM areas also reported very high concentration levels of $\mathrm{Hg}$, as was found by Ramírez Requelme et al. [4], who focused on the Nambija district, or as was found by Velásquez-López et al., [5], who focused on the aforementioned Portovelo-Zaruma area. Nevertheless, recent studies show that $\mathrm{Hg}$ pollution levels are being reduced due to the change of artisanal methodologies from amalgamation to cyanidation [6]. 
The mining area of Ponce Enríquez is located in the southern part of Ecuador, in Azuay Province, approximately $460 \mathrm{~km}$ from Quito. This mining area was discovered by chance in 1982 after the country experienced a very heavy El Niño episode. Rain exposed previously unknown gold veins existing in the foothills of the Andes mountain range. For many years, gold extraction in the sector has been a primitive operation. In the mining area of Ponce Enríquez, the ore is extracted from the slopes of the mountains in horizontal tunnels, and is moved from the mountain to the processing area in mining cars that are manually pushed by the operator [7,8]. The beneficiation process is carried out in several plants, some of them using amalgamation, while the most modern plants use cyanidation; in all cases, the lack of efficiency is a common point along with the environmental damage [9]. Figure 1 shows one plant visited during the sampling campaign with the typical "chanchas" (amalgamation drums).

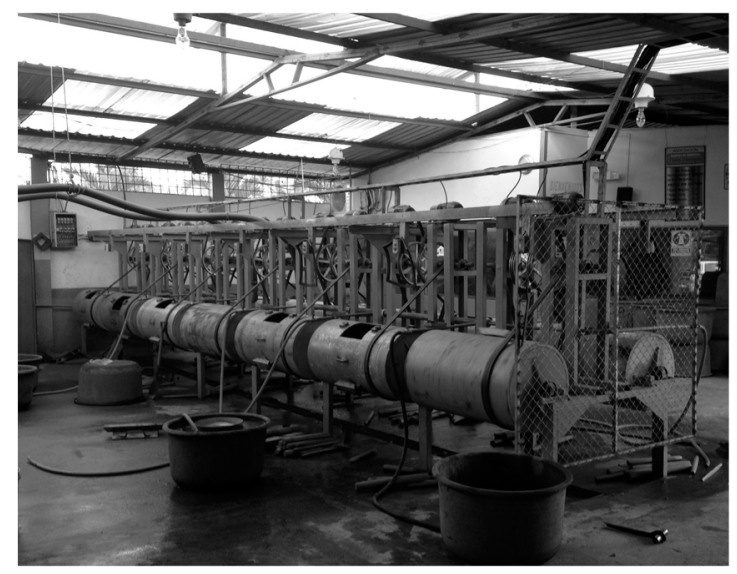

(a)

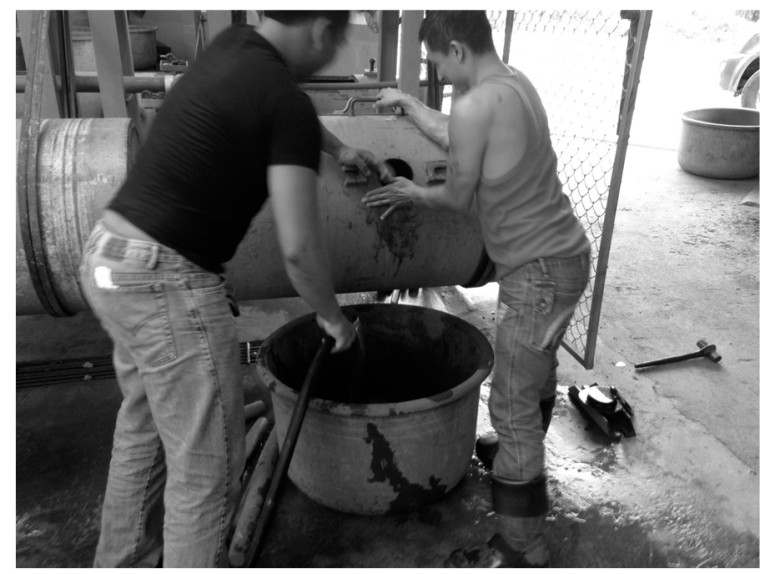

(b)

Figure 1. (a) "Chanchas" in a plant near Villa river, (b) Chancha discharge process.

Since the beginning of mining, there has been a lack of awareness of the long-term environmental consequences of the extractive processes. High gold values moved investors and miners to these remote areas of Ecuador where the mining was carried out regardless of the possible environmental consequences [10]. In 1998, the Swedish Environmental Services (SES) conducted a survey of river water pollution at several Ecuadorian locations, including the Ponce Enríquez area, where metal extraction mining was taking place [11]. The Prodeminca study [11] was the first to assess surface water quality in the area, but it focused on water contamination only. In 2002, the Ecuadorian government approved environmental regulations that allowed the protection of air, soil, water, and biotic resources [12]. Later in 2003, Ecuador's Environmental Ministry and the Energy and Mining Ministry targeted a new evaluation in the Ponce Enríquez area. The resulting report included a census of all mining operations and sediment monitoring of rivers, especially the Siete River [12].

At present, Ponce Enríquez has developed into a very active mining community. The area has a concentration of mining processing plants including facilities for grinding, gravity separation and leaching with cyanide. Arsenic and other heavy metals are generated as a by-product of the mining industry [13-15]. It is estimated that annually the area removed about 100,000 tons of ore with a production of approximately 15 tons of gold [16]. Approximately 10,000 tons of mining waste materials are discharged annually to the rivers in the sector [7].

Based on a geochemical and biological assessment of the mining tailings at Ponce Enríquez, Peña-Carpio and Menéndez-Aguado [17] showed that the mining tailings had a high potential to contaminate the surrounding waters and river sediments. Using statistical approaches, Sierra et al. [18] assessed the particle distribution of the surface detrital sediment in the Ponce Enríquez mining tailings. This paper presents the results of a detailed subsurface sediment survey in the rivers Fermín, Fermín Norte, Guanache, Villa, and Siete. These four rivers cross the Ponce Enríquez town, as well as 
mines and processing operations on the west side of the Andes mountain range (Figure 1). The main objectives of this study were to assess the heavy metal contamination of the subsurface river sediment and to prioritize contaminated areas for further research. Due to the lack of standards for pollution levels in sediments in Ecuador, Canadian guidelines were used as interim sediment quality guidelines (ISQG) in this research to compare with the obtained results in subsurface sediments.

\section{Materials and Methods}

\subsection{Sample Collection}

Subsurface sediment samples were collected during several sampling campaigns in February 2015 along the Fermín, Fermín Norte (a tributary of the Fermín River), Guanache, Villa and Siete rivers. Sampling sites were selected considering small tributaries, proximity to mining activities or low energy areas. Samples were taken from underneath riverbanks with the help of a Peterson grab sampler. At each sampling location, a composite sample was obtained mixing at least four subsamples, taken at a depth of 5-10 cm along the transverse to the longitudinal axis of the river. Sampling points along each river are represented in Figure 2. Samples were taken with a grain size $<4 \mathrm{~mm}$, and total weight $0.5-1 \mathrm{~kg}$. Table 1 shows the number of sampling sites located on the four rivers under study.

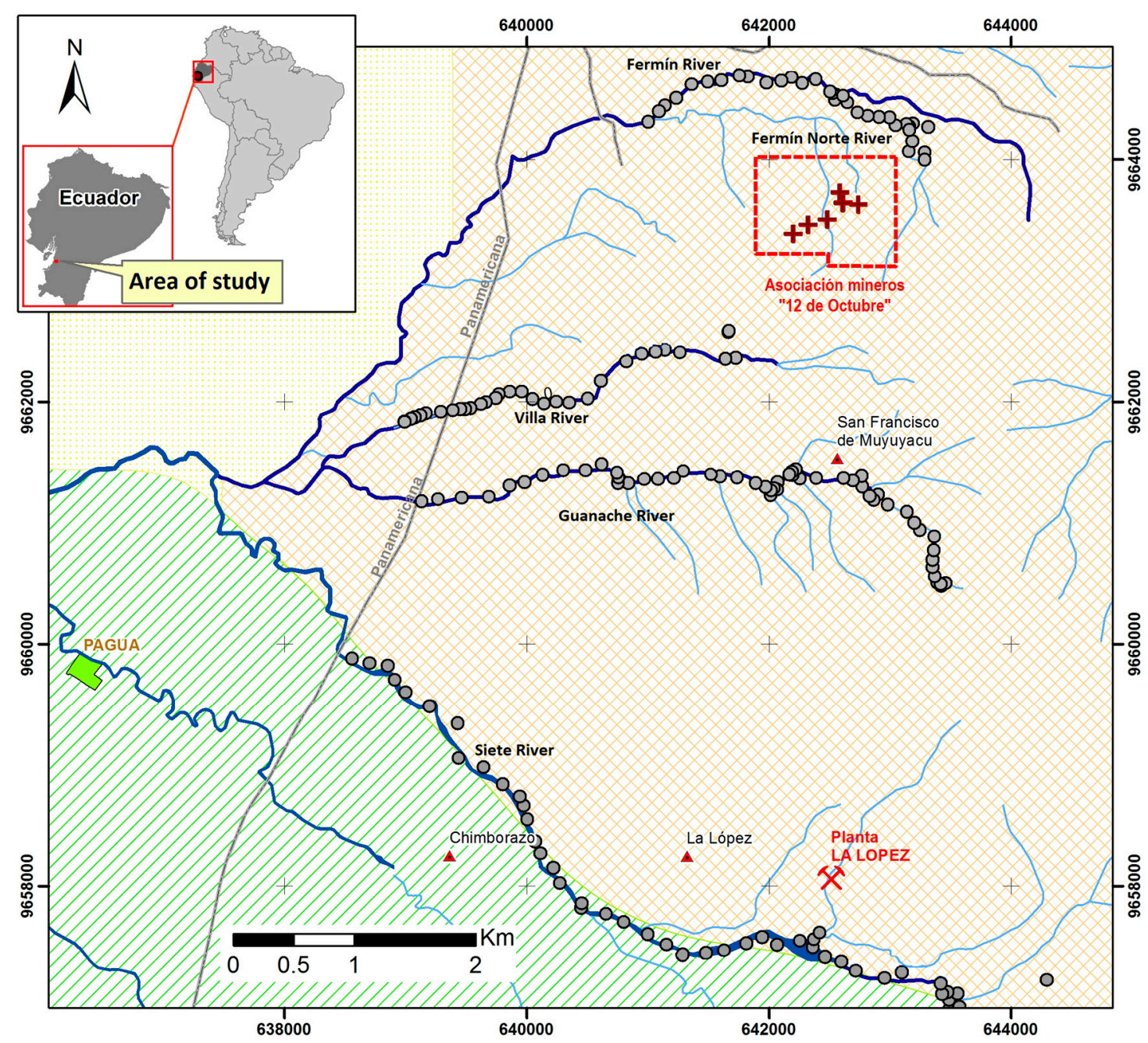

Figure 2. Area of study. 
Table 1. River length, altitude variations and sampling sites.

\begin{tabular}{ccccc}
\hline River & Length (km) & $\begin{array}{c}\text { Length Considered during } \\
\text { Water Sampling Campaign } \mathbf{( k m )}\end{array}$ & $\begin{array}{c}\text { Altitude Variation } \\
(\mathbf{m})\end{array}$ & $\begin{array}{c}\text { Number of } \\
\text { Sampling Sites }\end{array}$ \\
\hline Siete & 49.5 & 10 & 141 & 48 \\
Guanache & 5.6 & 5.6 & 548 & 56 \\
Fermín & 9.7 & 9.7 & 158 & 43 \\
Fermín & - & - & - & 34 \\
Norte & 3.6 & 3.6 & 211 & 33 \\
Villa & & & \\
\hline
\end{tabular}

\subsection{Sample Preparation and Analysis}

A total of 214 sampling stations were evaluated in the study area, and their locations are shown in Figure 2. All the samples were collected with grain size $<4 \mathrm{~mm}$ and kept in individual zip-lock bags for each sampling location. Each sampling bag was labeled and carefully sealed in order to avoid cross-contamination. The samples were dried in the laboratory at low temperature $\left(<40^{\circ}\right)$ to avoid evaporation losses.

The dried samples were ground and sieved through a 100 microns sieve before they were analyzed. For total heavy metal analysis, representative samples of $1.00 \mathrm{~g}$ were taken from each case using incremental sampling and digested in aqua regia to be analyzed by ICP-MS in an external certified laboratory (www.acmelab.com) in order to determine heavy metals concentration in part per million (ppm) of contaminants in the sediments.

Due to the lack of official standards for pollution levels in sediments in Ecuador, Canadian guidelines [19] were used as a reference in this study, although other standards were checked, following Burton et al. [20].

Statistix@ Analytical Software (version 10, www.statistix.com) was used to process and plot the measured data. Four parameters were calculated to evaluate the geochemical composition of the river sediment: The enrichment factor $(\mathrm{EF})$, the geo-accumulation index (Igeo), the contamination factor (Cf), and the pollution load index (PLI). The EF indicates the presence of contaminants via a calculated ratio of the elemental concentration of sediment, normalized to a background element. In this research, the reference element is an element particularly stable in soil, which is characterized by the absence of vertical mobility and/or degradation phenomena. Furthermore, its concentration should not be anthropogenically altered. The constituent chosen was iron (Fe). Fe has been observed to comprise as much as $11 \%$ of gold mine tailings in the Ponce Enríquez area. Ponce Enríquez area is rich in chalcopyrite and pyrrhotite, which are iron sulfides, and limonite, which is an oxidized form of Fe [17]. For this reason, Fe was used as a reference value for the present research.

$$
E F=[C n /(F e)] /[(\text { BaselineCn }) /(\text { BaselineFe })],
$$

where $\mathrm{Cn}$ is the element concentration.

Table 2 shows the established quality values for the enrichment factor [21]. In the present study, these values were applied to sediment.

Table 2. Enrichment factor values.

\begin{tabular}{cc}
\hline Values & Quality \\
\hline $\mathrm{EF}<2$ & Deficiency to minimal enrichment \\
$2<\mathrm{EF}<5$ & Moderate enrichment \\
$5<\mathrm{EF}<20$ & Significant enrichment \\
$20<\mathrm{EF}<40$ & Very high enrichment \\
\hline
\end{tabular}

The geo-accumulation index Igeo [21-23] was used to determine anthropogenic contamination in river sediments. The samples are generally classified as unpolluted $(0 \leq$ Igeo), unpolluted to 
moderately polluted $(0 \leq$ Igeo $\leq 1)$, moderately polluted $(1 \leq$ Igeo $\leq 2)$, moderate to strongly polluted $(2 \leq$ Igeo $\leq 3)$, strongly polluted $(3 \leq$ Igeo $\leq 4)$, strongly to extremely polluted $(4 \leq$ Igeo $\leq 5)$, and extremely polluted (Igeo $\geq 5$ ).

$$
\operatorname{Igeo}=\operatorname{Ln}[\mathrm{Cn} /(\mathrm{Bn})]
$$

where $B n$ is the mean background value for the element under study, obtained from the average values of soil samples of the study region.

The contamination factor $(C f)$ of heavy metals is expressed by the following equation:

$$
C f=C n / m e a n B n \text {. }
$$

This index $(C f)$ is considered an essential calculation in sediment pollution assessment.

Finally, the last parameter used to evaluate sediment contamination was the pollution load index (PLI) [24,25].

$$
\text { P.L.I. }=\left(C f_{1} \times C f_{2} \times C f_{3} \times C f_{4} \ldots . \times C f_{n}\right)^{1 / n}
$$

where the $C f s$ values are expressed as stated in Equation (3). Table 3 shows the PLI criterion [24].

Table 3. Pollution load index (PLI) criterion.

\begin{tabular}{cc}
\hline Values & Quality \\
\hline 0 & No pollution \\
1 & Background pollution \\
$>1$ & Elevated pollution level \\
\hline
\end{tabular}

\section{Results}

\subsection{Sediment Evaluation}

As mentioned above, Canadian guidelines [19] were used as interim sediment quality guidelines (ISQG) within this research, because Ecuador lacks standards for pollution levels in sediments. All or nearly all of the samples in each of the four rivers were above the ISQG guidelines for $\mathrm{Cu}, \mathrm{Ni}, \mathrm{As}$, and Cr. (Table 4). The mean Cu concentration in the $3.6 \mathrm{~km}$ long Villa River was 688 ppm (Table 5). The Guanache River had the second highest average $\mathrm{Cu}$ concentration in sediments with an average of 593 ppm. The third highest concentration was in the Siete and the lowest concentration was in the Fermín River. It is necessary to point out that these four rivers join to form the main stem Siete River. The portion of the Siete River sampled for this project was above the confluence, and thus, it was not affected by contamination from the other three rivers.

Table 4. Percentage of samples above the guidelines for sediment quality (ISQG) values.

\begin{tabular}{cccccccccc}
\hline Element & $\mathbf{C u}$ & $\mathbf{P b}$ & $\mathbf{Z n}$ & $\mathbf{N i}$ & As & Cd & Sb & Sr & Hg \\
\hline ISQG (ppm) & 18.7 & 35 & 123 & 21 & 5.9 & 0.7 & 2 & 2 & 0.17 \\
River Siete & $100 \%$ & $4 \%$ & $63 \%$ & $100 \%$ & $100 \%$ & $8 \%$ & $81 \%$ & $100 \%$ & $2 \%$ \\
River Guanache & $100 \%$ & $9 \%$ & $25 \%$ & $100 \%$ & $100 \%$ & $13 \%$ & $86 \%$ & $100 \%$ & $0 \%$ \\
River Fermín & $100 \%$ & $0 \%$ & $88 \%$ & $97 \%$ & $100 \%$ & $0 \%$ & $35 \%$ & $100 \%$ & $6 \%$ \\
River Villa & $100 \%$ & $6 \%$ & $3 \%$ & $100 \%$ & $100 \%$ & $3 \%$ & $100 \%$ & $100 \%$ & $36 \%$ \\
\hline
\end{tabular}


Table 5. Mean values and standard deviations among samples, by river. MDL is the method detection limit.

\begin{tabular}{lcccccccccc}
\hline River & Elements & $\mathbf{C u}$ & $\mathbf{P b}$ & $\mathbf{Z n}$ & $\mathbf{N i}$ & $\mathbf{A s}$ & $\mathbf{C d}$ & $\mathbf{S b}$ & $\mathbf{S r}$ & $\mathbf{H g}$ \\
\hline \multirow{5}{*}{ Siete } & MDL (ppm) & 1 & 3 & 1 & 1 & 2 & 0.5 & 3 & 1 & 1 \\
& ISQG (ppm) & 18.7 & 35 & 123 & 21 & 5.9 & 0.7 & 2 & 2 & 0.17 \\
\multirow{2}{*}{ Guanache } & mean & 483.7 & 20.3 & 132.5 & 5960.9 & 842.8 & 0.73 & 6.4 & 20.61 & 1.00 \\
& SD & 258.9 & 11.0 & 37.4 & 14.4 & 506.9 & 0.3 & 3.1 & 4.74 & 0.14 \\
Fermín & mD & 592.5 & 21.6 & 110.2 & 62.6 & 383.6 & 0.9 & 5.2 & 10.79 & under MDL \\
& mean & 256.0 & 10.1 & 32.0 & 11.8 & 273.2 & 0.3 & 2.4 & 5.37 & - \\
Villa & SD & 17.0 & 12.9 & 164.2 & 47.4 & 205.4 & under MDL & 4.0 & 26.35 & under MDL \\
& mean & 687.8 & 31.0 & 31.6 & 2.9 & 68.80 & - & 2.1 & 3.88 & - \\
& SD & 899.0 & 50.6 & 112.6 & 9.6 & 589.03 & 9.3 & 23.0 & 19.73 & 1.5 \\
\hline
\end{tabular}

In the Supplementary materials, the full results of ICP-MS analysis can be found for each sampling site of the full sampling campaign represented in Figure 2.

Figure 3 shows the variation between the sediment concentration and the sample location for $\mathrm{As}, \mathrm{Cu}, \mathrm{Pb}$, and $\mathrm{Hg}$ on the Fermín, Fermín Norte, Guanache Villa, and Siete rivers. Figure 4 shows the variation between the sediment concentration and the sample location for $\mathrm{Ni}, \mathrm{Sb}, \mathrm{Sr}$, and $\mathrm{Zn}$ on the same rivers. The Fermín Norte River is the upper part of the Fermín River, and has the lowest $\mathrm{Cu}$ concentration. Despite its short length, the Villa River showed a high standard deviation for $\mathrm{Cu}$, with a value of $899 \mathrm{ppm}$. In the case of the Villa River, there is a $211 \mathrm{~m}$ elevation difference between the first sample site on the slope of the Andes and the last sample site located only $25 \mathrm{~m}$ above sea level. The bottom slope of the river basin facilitates sediment transport and increases the contaminant concentration as it approaches the sea level. All the plots showed variations in sediment metal concentrations. Slope variation could also affect the results obtained, since all four rivers initiate their course at the banks of the Andes.
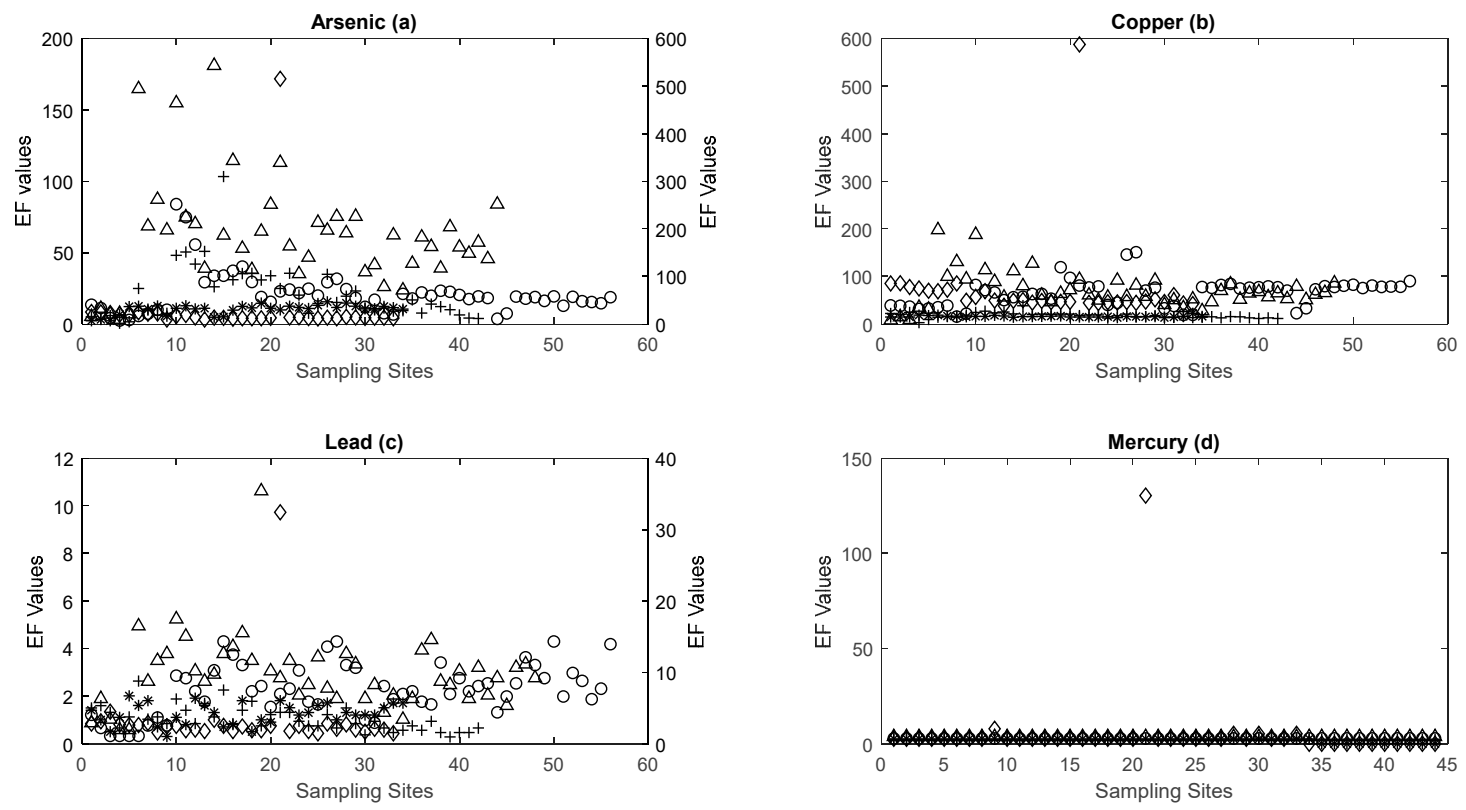

Figure 3. Downstream longitudinal sequence of EF for (a) As; (b) $\mathrm{Cu}$; (c) $\mathrm{Pb}$, and (d) $\mathrm{Hg}$. 


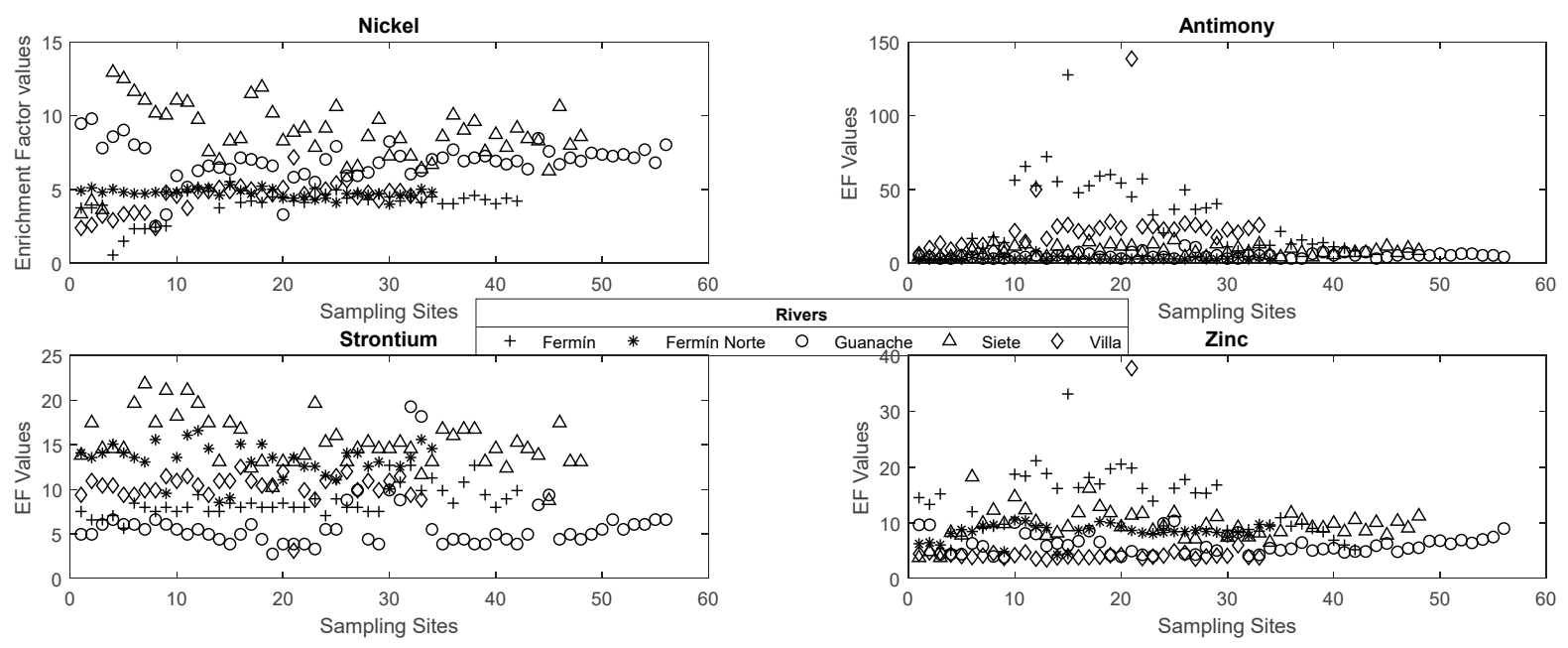

Figure 4. Downstream longitudinal sequence of $\mathrm{EF}$ for $\mathrm{Ni}, \mathrm{Sb}, \mathrm{Sr}$ and $\mathrm{Zn}$.

\subsection{Enrichment Factor (EF)}

The enrichment factor was evaluated for all the sampling sites defined in this study in the rivers at the Ponce Enríquez area. In the case of As, $97 \%$ of the sampling sites were above level 3, which means there was moderate enrichment in those sample sites; $40 \%$ of the sites had a value above 20 , and could be considered extremely enriched. These results were similar for most of the heavy metals analyzed.

Figures 3 and 4 plot the results for the EF index in a sequential way, from upstream to downstream. It must be clarified here that the sample process always started from the origin of each river, and the sampling sites were numbered in the downstream direction; that is, a sampling site with a smaller number than another means that it was taken upstream along the same river.

Regarding the EF variation, it was observed that $\mathrm{Hg}$ showed a very particular reaction. Even though $\mathrm{Hg}$ values were above the maximum contamination levels established for Canada, the obtained value was around $1 \mathrm{ppm}$ for almost every river. The exception was the Villa river, where two sampling sites had very high contamination values of 50 and $100 \mathrm{ppm}$. These values are shown as maximum values in Figure 3 and they corresponded with areas close to amalgamation plants, as shown in Figure 1.

\subsection{Geo-Accumulation Index (Igeo)}

The Igeo index was evaluated for all sampling sites of all four rivers in the Ponce Enríquez Area. For this parameter, $90 \%$ of the sampling sites were above level 3 , which means those sites should be considered as extremely polluted. Figure 5 shows values for $\mathrm{As}, \mathrm{Cu}, \mathrm{Pb}$, and $\mathrm{Hg}$, while Figure 6 addresses values for $\mathrm{Ni}, \mathrm{Sb}, \mathrm{Sr}$, and $\mathrm{Zn}$. 

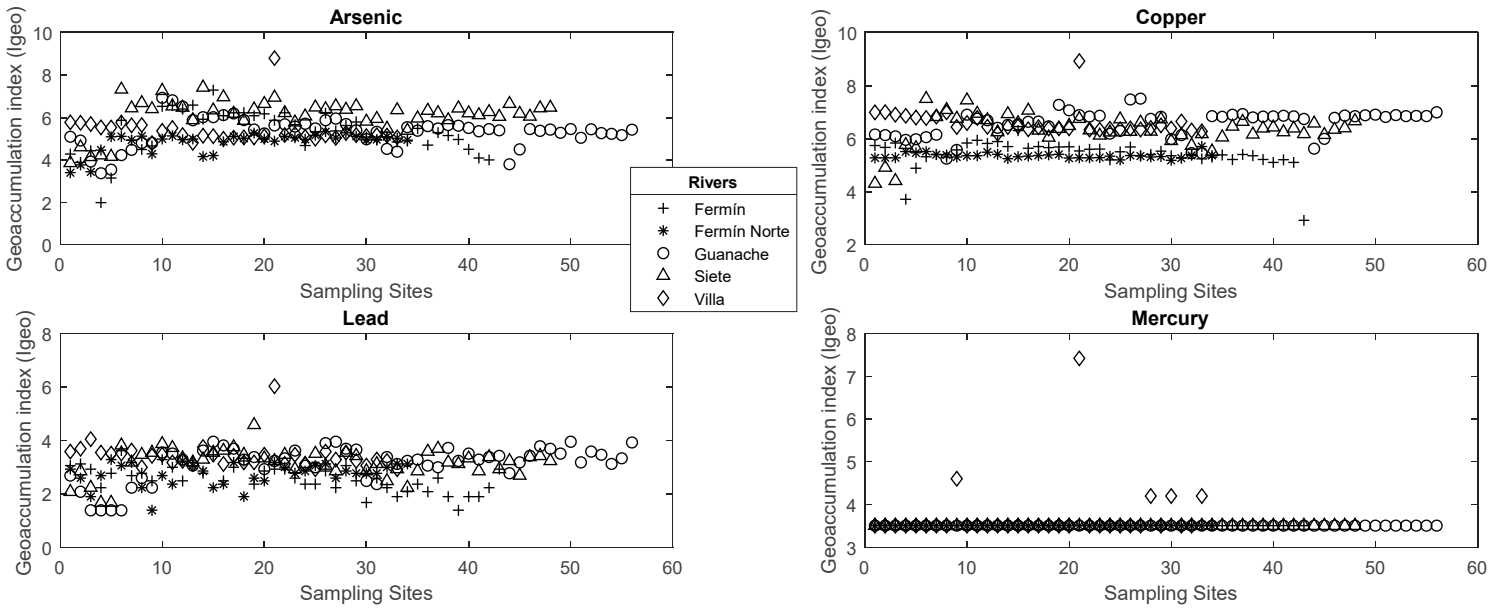

Figure 5. Downstream longitudinal sequence plots of Igeo for $\mathrm{As}, \mathrm{Cu}, \mathrm{Pb}$ and $\mathrm{Hg}$.
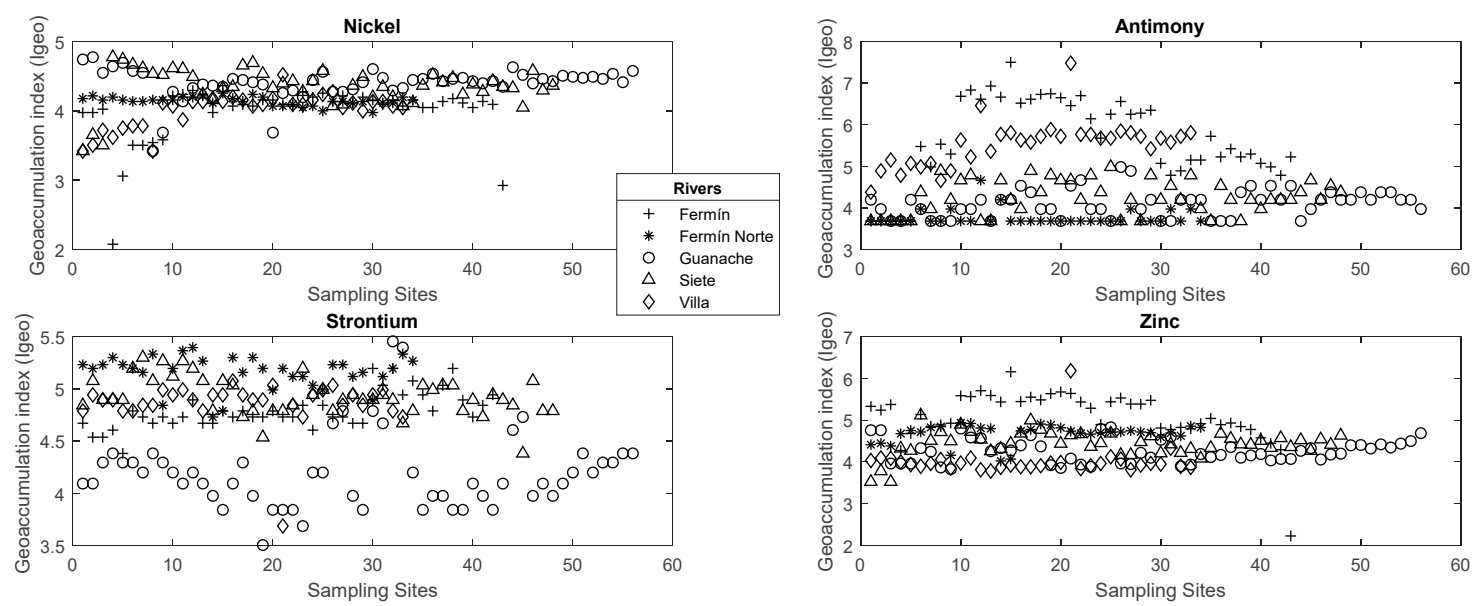

Figure 6. Downstream longitudinal sequence plots of Igeo for $\mathrm{Ni}, \mathrm{Sb}, \mathrm{Sr}, \mathrm{Zn}$.

\subsection{Contamination Factor (Cf)}

The contamination factor index was evaluated for every heavy metal in all sampling sites of all four rivers in the Ponce Enríquez Area; the results are shown in Figures 7 and 8. In the case of As, $100 \%$ of the sampling sites were found to be extremely contaminated.
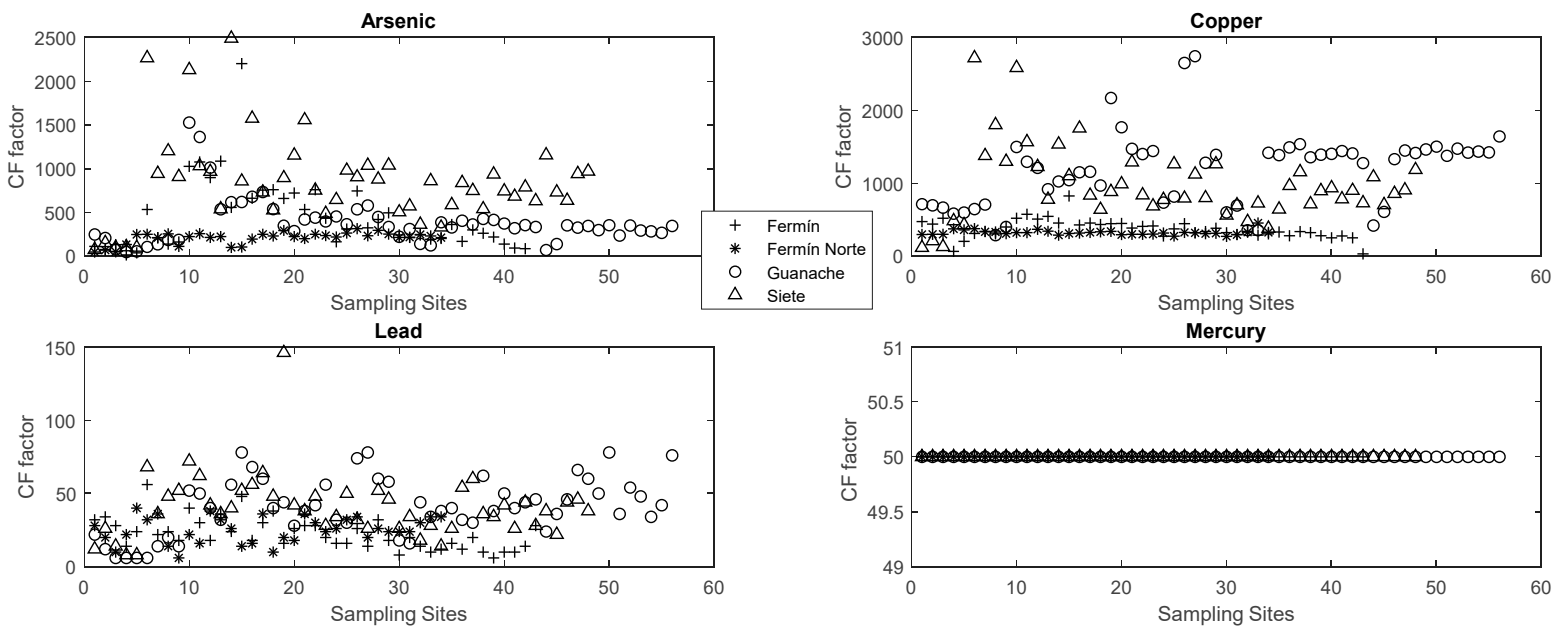

Figure 7. Downstream longitudinal sequence plots of contamination factor for $\mathrm{As}, \mathrm{Cu}, \mathrm{Pb}$ and $\mathrm{Hg}$. 

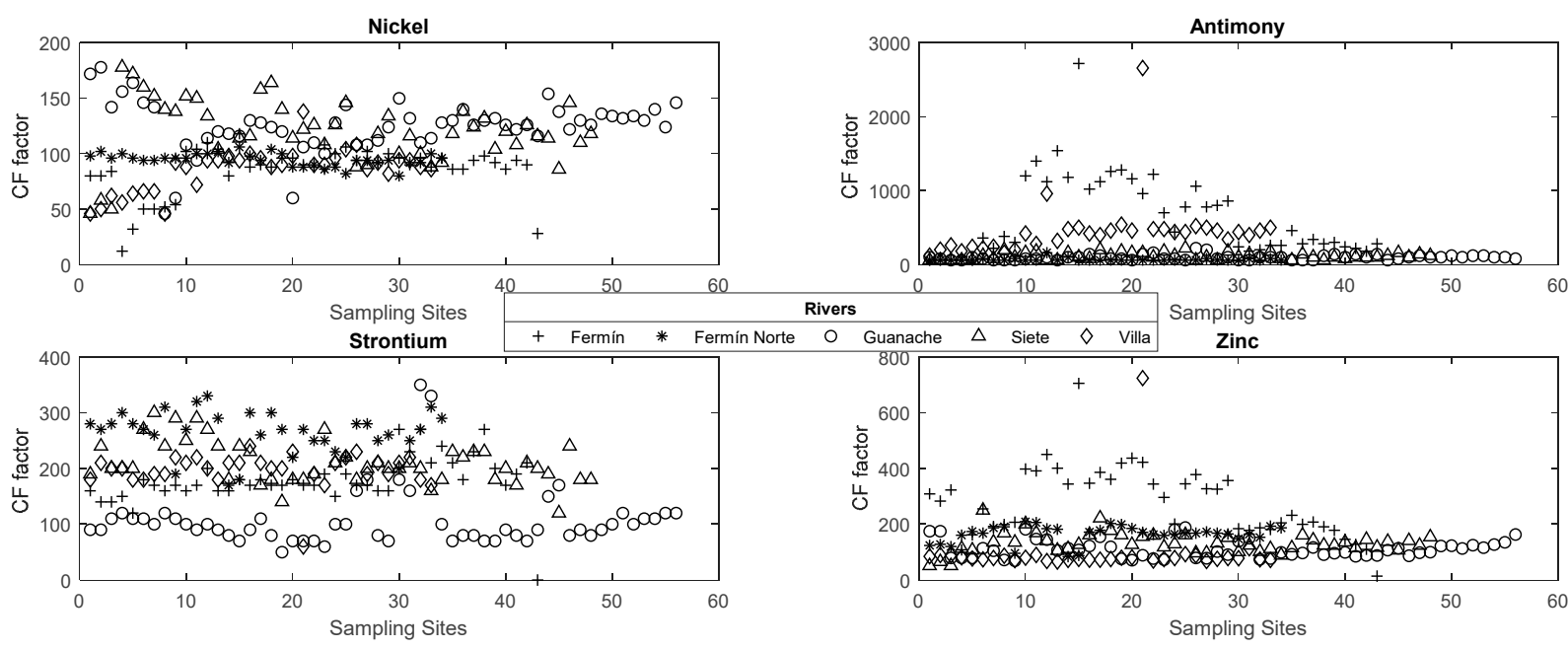

Figure 8. Downstream longitudinal sequence plots of contamination factor for $\mathrm{Ni}, \mathrm{Sb}, \mathrm{Sr}$ and $\mathrm{Zn}$.

\subsection{Pollution Load Index (PLI)}

The PLI, based on all nine heavy metals, was consistently above 1.0 at all sampling points, which means an elevated pollution level was present in all four rivers. Figure 9 shows the results for PLI in each case, and according to this index, the Siete River presents the highest PLI values.

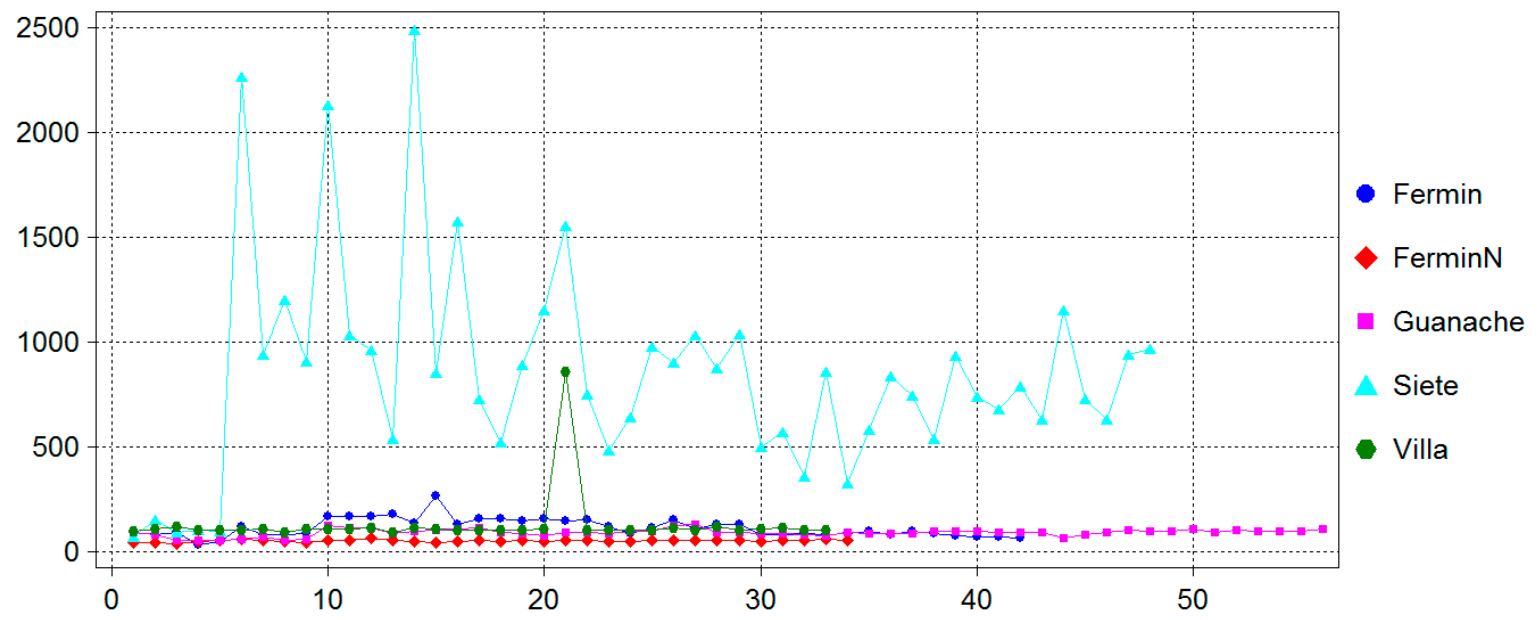

Figure 9. Downstream longitudinal sequence plot of the pollution load index values.

\section{Discussion}

The mining district of Ponce Enríquez is located within the subdistrict Machala-Narajal. It is known for its deposits of $\mathrm{Cu}, \mathrm{Au}$, and Mo in veins, breccias, stockworks, and epi-mesothermal deposits developed within volcanic rocks, and is spatially related to porphyry copper [26]. In this area, gold is associated with iron sulfides, arsenic sulfide, antimony, telurides, sulfides of copper, other sulfides such as galenite $(\mathrm{SPb})$ and sphalerite ( $\mathrm{SZn})$. In addition, sulfosalts, oxides of iron silicates, carbonates, micaceous minerals among others [27] are also associated with gold presence. In Ponce Enríquez, according to Peña Carpio and Menéndez-Aguado [17], the gold mineral paragenesis is sphalerite, pyrite, chalcopyrite, arsenopyrite, tetrahedrite, pyrrhotite, gold (III), tellurium, krennerite, and silica. For this reason, Fe was used as a reference value in determining the enrichment factors and the geo-accumulation index.

It is known that the presence of lead comes from galenite. This lead presence within the sediments comes from the grinding process in ore extraction, and its presence was noticeable in tailings in the Ponce Enríquez area. On the other hand, antimony comes from the presence of antimony sulfide. It has 
a mineral association with the mineral ores in the Ponce Enríquez area. Pyrrhotite and pentlandite are iron and nickel minerals that are also found in this area. The presence of strontium in the Macuchi formation is typical of the high sulfidation VHMS type [28], which is characteristic of Ponce Enríquez. The iron present within the analyzed sediments comes from iron oxides such as limonite and hematite common in the area.

The high levels of arsenic measured in sediments from the rivers Guanache and Fermín are possibly generated from mineral processing plants that are located in Ponce Enríquez area [18,29], like the one shown in Figure 1. In the case of copper, its presence is due to minerals such as chalcopyrite, cobelina, bornite, digenite, idaite (iron and copper sulfide), tennantite (copper and arsenic sulfide), and enargite (copper and arsenic sulfide). The existence of these minerals has been verified by previous studies [17]. In the case of enargite, this mineral is known for its high sulfidation, and is commonly found in VHMS deposits [28].

It can be observed in Figures 3-9 that all the analyzed indexes showed contamination levels in all rivers in the Ponce Enríquez area. The Siete River showed the highest contamination values for all the analyzed elements in the sample sediments, while the Fermín Norte River showed the lowest values. This could be related to the low presence of mining activities and mineral processing plants in that specific area in Ponce Enríquez. The presence of arsenic was above the maximum level in all the sediments analyzed.

Since 2010, Ecuadorian regulations prohibited mercury amalgamation as a gold recuperation process. Despite the existence of real difficulties to control and legalize ASGM activities that still use amalgamation, reports show evidence of some transition to cyanidation technologies in the ASGM areas [6]. Nevertheless, this is not the case for artisanal gold miners in Ponce Enríquez, and for this reason there are scattered sampling sites that reported high mercury concentrations.

It has been proven that some measures must be taken to avoid the undesirable impact of ASGM activities, without introducing the risk of social fracture. There is no doubt that increasing the availability of cleaner techniques in this area can be part of the solution, and the key probably lies in educational and long-term measures, as suggested in several research reports [30-32].

\section{Conclusions}

The project analyzed heavy metal pollutants in subsurface sediments from four rivers in the Ponce Enríquez mining area in Ecuador. A multi-index geochemical analysis indicated elevated heavy metal concentrations in all subsurface sediments in the studied river ecosystems. Fe concentrations was used as a reference value $(\mathrm{Bn})$ due to its existence in minerals such as chalcopyrite or limonite, which are alteration minerals ubiquitous in the Ponce Enríquez area.

The enrichment factors (EF) showed that all nine metals were enriched with the exception of $\mathrm{Hg}$, which was prohibited in anthropogenic sources within the mining industry.

The values obtained for EF from the Villa and Guanache rivers were very high at above $80 \%$, suggesting extremely contaminated sampling points. This was especially observed with the employment of the geo-accumulation index. Nevertheless, it is important to state that these values were obtained using Fe as a basic normalized constituent in the Ponce Enríquez area.

Some of the values for several heavy metals were above the maximum contaminant levels for $\mathrm{Cu}, \mathrm{Cr}, \mathrm{Sb}, \mathrm{As}$, and $\mathrm{Ni}$. Hg did not contribute much to the pollutant load index value, except for two scattered points on the Villa River. The Siete River exhibited the most longitudinal variability in metal concentrations.

In the case of the pollution load index, the results confirmed that all 214 sampling sites had an elevated pollution level. Illegal and informal mining activities are difficult to control and it is evident that they can contribute to environmental pollution in ASGM areas. The four indexes employed in this research in the Ponce Enríquez area showed high contamination along riverbanks in all four rivers under study. 
As a final conclusion, the need of urgent measures to avoid the undesirable impact of the ASGM activities has been proven, suggesting not only an increase in the availability of cleaner gold recovery techniques but also a need for the strong support of educational and long-term strategies.

Supplementary Materials: The following are available online at http:/ /www.mdpi.com/2073-4441/11/3/590/s1, Table S1: Full ICP-MS results at Fermín River, Table S2: Full ICP-MS results at Fermín Norte River, Table S3: Full ICP-MS results at Guanache River, Table S4: Full ICP-MS results at Villa River, Table S5: Full ICP-MS results at Siete River.

Author Contributions: Conceptualization, A.A.P. and E.P.C.; Methodology, J.M.M.-A. and A.A.P.; Software, A.A.P. and E.P.C.; Formal analysis, A.A.P.; Investigation, A.A.P. and J.M.M.-A.; Writing-original draft preparation, E.P.C., A.A.P. and T.V.; Writing-review and editing, J.M.M.-A. and M.M.M.L.; Supervision, J.M.M.-A.; Project administration, A.A.P. and E.P.C.; Funding acquisition, E.P.C. and J.M.M.-A.

Funding: This research received no external funding.

Acknowledgments: The authors want to thank to the Prometeo program developed by the Government of Ecuador (SENESCYT) which enabled the strengthening of research capabilities at the Escuela Superior Politécnica del Litoral (ESPOL) in Guayaquil.

Conflicts of Interest: The authors declare no conflict of interest.

\section{References}

1. Appleton, J.; Williams, T.; Orbea, H.; Carrasco, M. Fluvial contamination associated with artisanal gold mining in the Ponce Enriquez, Portovelo-Zaruma and Nambija areas. Ecuador. Water Air Soil Pollut. 2001, 131, 19-39. [CrossRef]

2. Valentukevičienè, M.; Bagdžiūnaitè-Litvinaitienè, L.; Chadyšas, V.; Litvinaitis, A. Evaluating the Impacts of Integrated Pollution on Water Quality of the Trans-Boundary Neris (Viliya) River. Sustainability 2018, 10, 4239. [CrossRef]

3. Ecuadorian Institute of Standardization NTE INEN 1 108:2011. Agua Potable. Requisitos. 2011. Available online: https:/ /law.resource.org/pub/ec/ibr/ec.nte.1108.2011.pdf (accessed on 9 March 2019).

4. Ramírez Requelme, M.E.; Ramos, J.F.F.; Angélica, R.S.; Brabo, E.S. Assessment of Hg-contamination in soils and stream sediments in the mineral district of Nambija, Ecuadorian Amazon (example of an impacted area affected by artisanal gold mining). Appl. Geochem. 2003, 18, 371-381. [CrossRef]

5. Velásquez-López, P.C.; Veiga, M.M.; Hall, K. Mercury balance in amalgamation in artisanal and small-scale gold mining: Identifying strategies for reducing environmental pollution in Portovelo-Zaruma, Ecuador. J. Clean. Prod. 2010, 18, 226-232. [CrossRef]

6. Gonçalves, A.O.; Marshall, B.G.; Kaplan, R.J.; Moreno-Chavez, J.; Veiga, M.M. Evidence of reduced mercury loss and increased use of cyanidation at gold processing centers in southern Ecuador. J. Clean. Prod. 2017, 165, 836-845. [CrossRef]

7. Sandoval, F. Small-Scale Mining in the Ecuador, Mining, Minerals and Sustainable Development. 2001. Available online: http:/ / pubs.iied.org/pdfs/G00720.pdf (accessed on 20 February 2019).

8. Mendieta, G.; Wilfrido, R. Plan de Desarrollo y Ordenamiento Territorial del cantón Camilo Ponce Enríquez Fase de Actualización 2014-2015. 2016. Available online: http:/ / dspace.ucuenca.edu.ec/handle/123456789/ 23513 (accessed on 20 February 2019).

9. Palapa, T.; Maramis, A. Heavy Metals in Water of Stream Near an Amalgamation Tailing Ponds in Talawaan-Tatelu Gold Mining, North Sulawesi, Indonesia. Procedia Chem. 2015, 14, 428-436. [CrossRef]

10. Carrillo, G.R.; Astudillo, A.A. Evaluación de las emisiones de vapor mercurial en procesos de amalgamado artesanal: Caso Cantón Ponce Enríquez, Provincia del Azuay. Maskana 2011, 2, 2. Available online: http: / / dspace.ucuenca.edu.ec/bitstream/123456789/5422/1/MASKANA\%20si7285\%20(6).pdf (accessed on 20 February 2019). [CrossRef]

11. Prodeminca. Monitoreo Ambiental de las áreas mineras en el sur del Ecuador; Prodeminca: Quito, Ecuador, 1998; ISBN 997840872X.

12. Ministerio del Ambiente y Ministerio de Energía y Minas. Examen Especial al Control de Explotación Minera en las Cuencas de los ríos Santa Rosa, Caluguro, Tenguel y Siete; A cargo de la Dirección Regional de Minería de El Oro; Ministerio del Ambiente y Ministerio de Energía y Minas: Quito, Ecuador, 2003. 
13. Ackerman, F. A procedure for correcting the grain size effect in heavy metal analyses of estuarine and coastal sediments. Environ. Technol. Lett. 1980, 1, 518-527. [CrossRef]

14. Moore, F.; Forghani, G.; Qishlaqi, A. Assessment of heavy metal contamination in water and surface sediments of the Maharlu saline lake, SW Iran. Iran. J. Sci. Technol. Trans. 2009, 33, 43-55.

15. Khalil, A.; Hanich, L.; Bannari, A.; Zouhri, L.; Pourret, O.; Hakkou, R. Assessment of soil contamination around an abandoned mine in a semi-arid environment using geochemistry and geostatistics: Pre-work of geochemical process modeling with numerical models. J. Geochem. Explor. 2013, 125, 117-129. [CrossRef]

16. Banco Central del Ecuador, Reporte de Minería. 2018. Available online: https://contenido.bce.fin.ec/ documentos/Estadisticas/Hidrocarburos/ReporteMinero012018.pdf (accessed on 20 February 2019).

17. Peña Carpio, E.; Menéndez-Aguado, J.M. Environmental study of gold mining tailings in the Ponce Enriquez mining area (Ecuador). Dyna 2016, 83, 237-245. [CrossRef]

18. Sierra, C.; Ruiz-Barzola, O.; Menéndez, M.; Demey, J.; Vicente-Villardón, J. Geomechanical interactions study in surface river sediments at an artisanal mining area by means of Conical (Manova)-Biplot. J. Geochem. Explor. 2017, 175, 72-81. [CrossRef]

19. Canadian Council of Ministers. Canadian Sediment Quality Guidelines for the Protection of Aquatic Life. 1999. Available online: https:http: / / ceqg-rcqe.ccme.ca/en/index.html (accessed on 20 February 2019).

20. Burton, G.A.; Kumagai, M.; Hashitani, H.; Tanimoto, R. Sediment quality criteria in use around the world. Jpn. J. Limnol. 2004, 65, 117-134.

21. Barbieri, M. The Importance of Enrichment Factor (EF) and Geoaccumulation Index (Igeo) to Evaluate the Soil Contamination. Geol. Geophys. 2016, 5, 237. [CrossRef]

22. Gupta, S.; Vinod, J.; Matic, N.; Kapralova, V.; Solanki, J. Assessment of Geo-Accumulation Index of Heavy Metal and Source of Contamination by Multivariate Factor Analysis. Int. J. Hazard. Mater. 2014, 18, 18-22.

23. Ji, H.; Li, H.; Zhang, Y.; Ding, H.; Gao, Y.; Xing, Y. Distribution and risk assessment of heavy metals in overlying water, porewater, and sediments of Yongding River in a coal mine brownfield. J. Soils Sediments 2018, 18, 624-639. [CrossRef]

24. Tomlinson, D.C.; Wilson, J.G.; Harris, C.R.; Jeffrey, D.W. Problems in the assessment of heavy-metal levels in estuaries and the formation of a pollution index. Helgol. Mar. Res. 1980, 33, 566-575. [CrossRef]

25. Adebowale, K.O.; Agunbide, F.O.; Olu-Owolabi, B. Trace metal concentration, site variations and partitioning pattern in water and bottom sediments from coastal area: A case study of Ondo Coast, Nigeria. Environ. Res. J. 2009, 3, 46-59.

26. Jordá, B.R.; Romero, P.; Peña Carpio, E.; Jiménez, S.; Garcés, D.; Chang, R. Análisis preliminar de la estabilidad de escombreras y balsa de relaves en el Distrito Minero Ponce Enríquez, Ecuador. In Proceedings of the 15th LACCEI International Multi-Conference for Engineering, Education, and Technology: “Global Partnerships for Development and Engineering Education", Boca Raton, FL, USA, 19-21 July 2017.

27. Chiaradia, M.; Ulianov, A.; Kouzmanov, K.; Beate, B. Why large porphyry Cu deposits like high Sr/Y mASGMas? Sci. Rep. 2, 2012, 685. [CrossRef]

28. Chiaradia, M.; Fontboté, L. Gold Rich VHMS deposits of the western cordillera of Ecuador: Mineralogy, lead isotope and metal geochemistry. In VMS Deposits of Latin America; Geological Association of Canada: St. John's, NL, Canada, 2000; pp. 333-339.

29. Wang, S.; Mulligan, C.N. Occurrence of Arsenic Contamination in Canada: Sources, Behavior and Distribution. Sci. Total Environ. 2006, 366, 701-721. [CrossRef]

30. Hinton, J.J.; Veiga, M.M.; Veiga, A.; Tadeu, C. Clean artisanal gold mining: A utopian approach? J. Clean. Prod. 2003, 11, 99-115. [CrossRef]

31. Hinton, J.J.; Veiga, M.M.; Beinhoff, C. Women, mercury and artisanal gold mining: Risk communication, and mitigation. J. Phys. 2003, 107, 617-620. [CrossRef]

32. Veiga, M.M.; Marshall, B.G. Teaching artisanal miners about mercury pollution using songs. Extr. Ind. Soc. 2017, 4, 842-845. [CrossRef]

(C) 2019 by the authors. Licensee MDPI, Basel, Switzerland. This article is an open access article distributed under the terms and conditions of the Creative Commons Attribution (CC BY) license (http:/ / creativecommons.org/licenses/by/4.0/). 